\title{
PENGARUH PERBEDAAN ARAS STARTER PADA FERMENTASI SABUT KELAPA TERHADAP KECERNAAN BAHAN PAKAN DAN PRODUKSI VOLATILE FATTY ACIDS SECARA IN VITRO
}

\section{The Effect of Starter Level on Fermentation Coconut Coir to Feed Digestibility and Volatile Fatty Acids Production with In Vitro Method}

\author{
Aulia Rahman*, Sunarso, B.I.M. Tampoebolon, L.K. Nuswantara \\ Faculty of Animal and Agricultural Science, University of Diponegoro \\ Ds. Dudakawu RT 03/05, Kembang, Jepara, Jawa Tengah, 59457 \\ *E-mail : aulia180597@gmail.com
}

Submitted : April 8, $2020 \quad$ Accepted : July 11, 2020

\begin{abstract}
ABSTRAK
Penelitian ini bertujuan untuk mengkaji pengaruh aras starter pada fermentasi sabut kelapa terhadap Kecernaan Bahan Kering (KcBK), Kecernaan Bahan Organik (KcBO) dan Volatile Fatty Acids (VFA) dengan metode in vitro. Rancangan percobaan yang digunakan adalah Rancangan Acak Lengkap (RAL). Percobaan terdiri dari 4 perlakuan aras starter yaitu $\mathrm{T}_{0}$ (fermentasi sabut kelapa $+0 \%$ starter), $\mathrm{T}_{1}$ (fermentasi sabut kelapa $+2 \%$ starter), $\mathrm{T}_{2}$ (fermentasi sabut kelapa $+4 \%$ starter), dan $\mathrm{T}_{3}$ (fermentasi sabut kelapa $+6 \%$ starter) dengan 5 ulangan tiap perlakuan dan lama fermentasi 10 hari. Hasil penelitian menunjukkan sabut kelapa yang difermentasi dengan aras starter sampai 6\% dapat meningkatkan $(\mathrm{P}<0,05) \mathrm{KcBK}$ dan $\mathrm{KcBO}$ tetapi berpengaruh tidak nyata pada VFA. Rata-rata nilai $\mathrm{KcBK}$ dan $\mathrm{KcBO}$ pada perlakuan $\mathrm{T}_{0}, \mathrm{~T}_{1}, \mathrm{~T}_{2}$ dan $\mathrm{T}_{3}$ berturut-turut adalah KcBK 28,08\%; 30,71\%; 34,27\%; 35,78\% dan KcBO 28,73\%; 31,81\%; 35,21\%; $36,88 \%$. Rata-rata nilai produksi VFA pada perlakuan $\mathrm{T}_{0}, \mathrm{~T}_{1}, \mathrm{~T}_{2}$ dan $\mathrm{T}_{3}$ berturut-turut adalah $130 \mathrm{mM}, 125$ $\mathrm{mM}, 118 \mathrm{mM}$ dan $120 \mathrm{mM}$. Simpulan penelitian adalah pemberian aras starter mampu meningkatkan KcBK dan KcBO dan produksi VFA memiliki kecenderungan menurun serta pemberian aras starter optimal pada level $4 \%$.
\end{abstract}

Kata kunci : Fermentasi, In vitro, Kecernaan, Sabut kelapa, Volatile fatty acid.

\section{ABSTRACT}

This study aimed to examine the effect of starter level on coconut coir fermentation on Dry Matter Digestibility (DMD), Organic Matter Digestibility (OMD) and Volatile Fatty Acids (VFA) with in vitro method. The experimental design used was a Completely Randomized Design (CRD). The experiment consisted of 4 starter level treatments namely $T_{0}$ (coconut coir fermentation $+0 \%$ starter), $T_{1}$ (coconut coir fermentation $+2 \%$ starter), $T_{2}$ (coconut coir fermentation $+4 \%$ starter), and $T_{3}$ (coconut coir fermentation $+6 \%$ starter) with 5 replications per treatment and 10 days fermentation for all treatment. The results showed that coconut coir fermented with starter level up to $6 \%$ could increase $(P<0.05)$ DMD and OMD but had no significant effect on VFA. The average DMD and OMD values for $T_{0}, T_{1}, T_{2}$ and $T_{3}$ treatments consecutively were DMD 28,08\%; 30,71\%; 34,27\%; 35,78\% and OMD 28,73\%; 31,81\%; 35,21\%; $36,88 \%$. The average value of VFA production in $T_{0}, T_{1}, T_{2}$ and $T_{3}$ treatments consecutively were $130 \mathrm{mM}$, $125 \mathrm{mM}, 118 \mathrm{mM}$ and $120 \mathrm{mM}$. The conclusion of this study was the level of starter was able to increase DMD and OMD but production of VFA had a downward trend with the optimal level of starter was $4 \%$.

Keywords: Coconut coir, Digestibility, Fermentation, In vitro, Volatile fatty acid. 


\section{PENDAHULUAN}

Pakan ternak merupakan salah satu faktor penentu dalam usaha peternakan karena berguna untuk kelangsungan hidup pokok, produksi dan reproduksi ternak tetapi ketersediaan hijauan pakan seringkali tidak menentu dan tergantung pada musim. Ketersediaan pakan saat musim kemarau seringkali terbatas, sehingga perlu adanya pakan alternatif.

Sabut kelapa salah satu sisa hasil perkebunan yang berpotensi menjadi pakan alternatif bagi ternak ruminansia, karena luas lahan perkebunan kelapa di Indonesia pada tahun 2017, yaitu 2.619.264 Ha dengan produksi 2.871.280 ton dan pada produksi kelapa di Jawa Tengah sebesar 158.749 ton dengan luas area 225.252 Ha (Ditjenbun, 2016). Produksi kelapa yang tinggi dan pemanfaatan limbah kelapa tidak lebih dari 3\% mengakibatkan sabut kelapa berpotensi menjadi pakan alternatif (Bondra et al., 2018). Sabut kelapa mengandung serat kasar 30,34\% dan kadar abu 3,95\% (Oladayo, 2010). Kandungan serat kasar yang semakin tinggi pada bahan pakan dapat mengakibatkan kecernaan pakan semakin rendah (Riswandi et al., 2015). Kualitas pakan dapat ditingkatkan dengan melakukan pengolahan pakan secara fisik, kimia, biologis atau gabungan.

Fermentasi pakan merupakan salah satu pengolahan pakan secara biologis. Fermentasi pakan dapat merubah senyawa kompleks menjadi senyawa yang lebih sederhana dengan memanfaatkan mikroorganisme (Soares et al., 2018). Serat kasar yang terkandung dalam sabut kelapa dapat diturunkan dengan fermentasi pakan. Serat kasar yang turun mengakibatkan aktivitas degradasi mikrobia dalam rumen meningkat, sehingga kecernaan bahan kering $(\mathrm{KcBK})$ dan kecernaan bahan organik $(\mathrm{KcBO})$ meningkat. Peningkaatan kecernaan bahan pakan mengakibatkan produksi volatile fatty acids (VFA) meningkat. Produksi VFA berhubungan dengan fermentabilitas karbohidrat di dalam rumen oleh aktivitas mikrobia rumen karena sebagian besar VFA diperoleh dari fermentabilitas karbohidrat pakan (Muchlas et al., 2014). Ruminansia menjadikan VFA menjadi sumber energi utama (Rahayu et al., 2018). Tujuan penelitian untuk mengkaji pengaruh perbedaan aras starter pada fermentasi sabut kelapa terhadap KcBK, KcBO dan produksi VFA pada sabut kelapa.

\section{MATERI DAN METODE}

Penelitian dilaksanakan pada bulan November 2018 sampai Maret 2019 di Laboratorium Ilmu Nutrisi Pakan, Fakultas Peternakan dan Pertanian, Universitas Diponegoro, Semarang.

\section{Materi}

Materi yang digunakan adalah sabut kelapa, starter komersial "Profeed", urea, molasses, cairan rumen sapi Simental, larutan McDougall, larutan pepsin- $\mathrm{HCl}$, aquades, gas $\mathrm{CO}_{2}$, kertas saring "Whatman no.41", $\mathrm{NaOH}$ $0,5 \mathrm{~N}, \mathrm{H}_{2} \mathrm{SO}_{4} 15 \%$, indikator phenolphthalein (PP) $1 \%$, alkohol $70 \%$, aseton, dan $\mathrm{HCl} 0,5 \mathrm{~N}$. Alat yang digunakan yaitu grinder, autoclave, erlenmeyer, beker glass, spet ukuran $5 \mathrm{ml}$ dan 3 $\mathrm{ml}$, blender, freezer, nampan, bunsen, botol fermentor, dry box, gelas ukur $50 \mathrm{ml}$ dan $25 \mathrm{ml}$, tabung $\mathrm{CO}_{2}$, timbangan analitik, tabung fermentor, tutup fermentor, waterbath, centrifuge, botol 50ml, tabung destilasi, labu pendingin, tanur listrik, oven, buret.

\section{Metode}

Metode penelitian secara eksperimental dengan menggunakan Rancangan Acak Lengkap (RAL). Penelitian menggunakan 4 perlakuan dan tiap perlakuan 5 ulangan. Penelitian dilakukan melalui 3 tahap: 1) tahap pertama persiapan alat dan bahan meliputi pengadaan bahan, sterilisasi alat dan bahan; 2) tahap kedua pembuatan fermentasi sabut kelapa dengan lama fermentasi 10 hari; 3) tahap ketiga analisis in vitro. Perlakuan penelitian sebagai berikut:

T0 : sabut kelapa fermentasi tanpa penambahan starter Profeed

T1 : sabut kelapa fermentasi dengan starter Profeed 2\% dari BK sabut kelapa

T2 : sabut kelapa fermentasi dengan starter Profeed 4\% dari BK sabut kelapa

T3 : sabut kelapa fermentasi dengan starter Profeed 6\% dari BK sabut kelapa

Parameter yang diamati adalah KcBK, KcBO dan produksi VFA. Kecernaan bahan kering dan $\mathrm{KcBO}$ menggunakan metode Tilley dan Terry (1963). Produksi VFA menggunakan metode Steam Destilation (Departement of Dairy Science, 1966). Rumus yang digunakan untuk mengukur $\mathrm{KcBK}, \mathrm{KcBO}$ dan VFA menurut Widodo et al. (2012) sebagai berikut: 
$\operatorname{KcBK}(\%)=$

$\underline{\text { Bobot BK sampel (g) - Bobot BK residu (g) - Bobot BK blanko (g) }}$ X100 Bobot BK awal (g)

$\operatorname{KcBO}(\%)=$

$\frac{\text { Bobot BO sampel (g) - Bobot BO residu (g) - Bobot BO blanko (g) }}{\text { Bobot BO awal (g) }}$ X100

VFA total $(\mathrm{mM})=(\mathrm{a}-\mathrm{b}) \times \mathrm{N}-\mathrm{HCl} \times\left(\frac{1000}{5}\right)$

\section{HASIL DAN PEMBAHASAN}

Nilai rataan $\mathrm{KcBK}, \mathrm{KcBO}$, dan produksi VFA pada sabut kelapa difermentasi dengan perlakuan perbedaan aras starter ditampilkan pada Tabel 1.

\section{Kecernaan Bahan Kering}

Berdasarkan analisis ragam pada perlakuan perbedaan aras starter berpengaruh nyata $(\mathrm{P}<0,05)$ meningkatkan Kecernaan Bahan Kering (KcBK) pada sabut kelapa yang telah difermentasi. Peningkatan KcBK sabut kelapa diakibatkan oleh ikatan lignin yang terkandung dalam sabut kelapa terhadap selulosa dan hemiselulosa merenggang akibat proses fermentasi. Simbolon et al., (2016) menyatakan penggunaan bakteri penghasil enzim selulase pada fermentasi bahan pakan dapat melonggarkan ikatan kompleks ligno selulosa dan ligno hemiselulosa, sehingga kecernaan bahan kering meningkat. Bakteri selulolitik dan hemiselulolitik yang terkandung dalam starter dalam fermentasi sabut kelapa akan menghasilkan enzim selulase dan hemiselulase yang akan merenggangkan ikatan ligno selulosa dan ligno hemiselulosa. Ikatan lignin yang semakin merenggang akan meningkatkan kecernaan karena lignin memiliki degradabilitas yang rendah. Anindyawati (2009) menyatakan enzim yang berperan dalam degradasi ligno selulosa adalah enzim yang bersifat selulolitik, hemiselulolitik dan lignolitik.

Kecernaan bahan kering pada sabut kelapa difermentasi pada perlakuan $\mathrm{T}_{0}, \mathrm{~T}_{1}, \mathrm{~T}_{2}, \mathrm{~T}_{3}$ berturut-turut yaitu, 28,08\%, 30,71\%, 34,27\% dan $35,78 \%$ (Tabel 1 dan Gambar 1). Hasil uji statistik pada pemberian aras starter $6 \% \quad\left(\mathrm{~T}_{3}: 35,78 \%\right)$ memiliki rataan $\mathrm{KcBK}$ tertinggi dan berbeda tidak nyata dengan aras $4 \% \quad\left(\mathrm{~T}_{2}: 34,27 \%\right)$ tetapi berpengaruh nyata lebih tinggi dari aras $2 \%$ $\left(\mathrm{T}_{1}: 30,71 \%\right)$ dan $0 \%\left(\mathrm{~T}_{0}: 28,08 \%\right)$. Nilai rataan KcBK relatif rendah tetapi mengalami peningkatan pada perlakuan aras yang semakin tinggi dengan pemberian optimal pada perlakuan aras starter $\mathrm{T}_{2}(4 \%)$, dan pada perlakuan $\mathrm{T}_{3}(6 \%)$ menunjukkan kenaikan yang berbeda tidak nyata. Fathul dan Wajizah (2010) menyatakan kecernaan bahan pakan yang baik memiliki nilai lebih dari $60 \%$.

Nilai KcBK yang meningkat menunjukkaan ikatan ligno selulosa dan ligno hemiselulosa merenggang akibat bahan pakan difermentasi menggunakan starter yang mengandung bakteri selulolitik dan hemiselulolitik. Sukarti et al., (2012) menyatakan bahwa fermentasi dapat mengubah senyawa kompleks dalam bahan pakan menjadi lebih sederhana melalui aktivitas mikrobia. Faktor lain yang dapat mempengaruhi $\mathrm{KcBK}$ yaitu anti nutrien tanin yang terkandung pada sabut kelapa diduga menurun selama proses fermentasi bahan pakan. Tanin akan membentuk proteksi pada nutrien yang akan mengurangi kemampuan degradasi mikrobia. Fariani dan Akhadiarto (2011) menyatakan bahwa tanin merupakan salah satu anti nutrien pada pakan yang dapat menurunkan kecernaan dan palatabilitas serta dapat menurunkan aktifitas degradasi mikrobia akibat tanin mengikat nutrien pakan.

Tabel 1. Nilai rataan KcBK, KcBO dan VFA pada sabut kelapa difermentasi.

The Mean Values of DMD, OMD and VFA's on Fermented Coconut Coir.

\begin{tabular}{lrrrr}
\hline \multirow{2}{*}{ Parameter } & \multicolumn{5}{c}{ Perlakuan } \\
& \multicolumn{5}{c}{ Treatment } \\
\cline { 2 - 5 } & $\mathbf{T}_{\mathbf{0}}$ & $\mathbf{T}_{\mathbf{1}}$ & $\mathbf{T}_{\mathbf{2}}$ & \multicolumn{1}{c}{$\mathbf{T}_{\mathbf{3}}$} \\
\hline KcBK/DMD (\%) & $28,08^{\mathrm{c}}$ & $30,71^{\mathrm{b}}$ & $34,27^{\mathrm{a}}$ & $35,78^{\mathrm{a}}$ \\
KcBO/OMD (\%) & $28,73^{\mathrm{c}}$ & $31,81^{\mathrm{b}}$ & $35,21^{\mathrm{a}}$ & $36,88^{\mathrm{a}}$ \\
VFA/VFA's (mM) & 130 & 125 & 118 & 120 \\
\hline
\end{tabular}

Keterangan : Superskrip yang berbeda pada baris yang sama menunjukkan perbedaan nyata $(\mathrm{P} \leq 0,05)$. Different superscripts on the same line show real differences $(P \leq 0,05)$. 


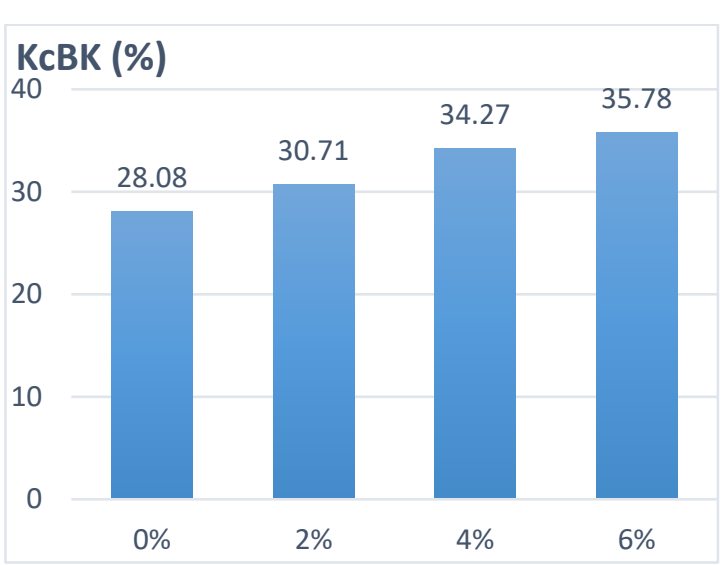

(a)

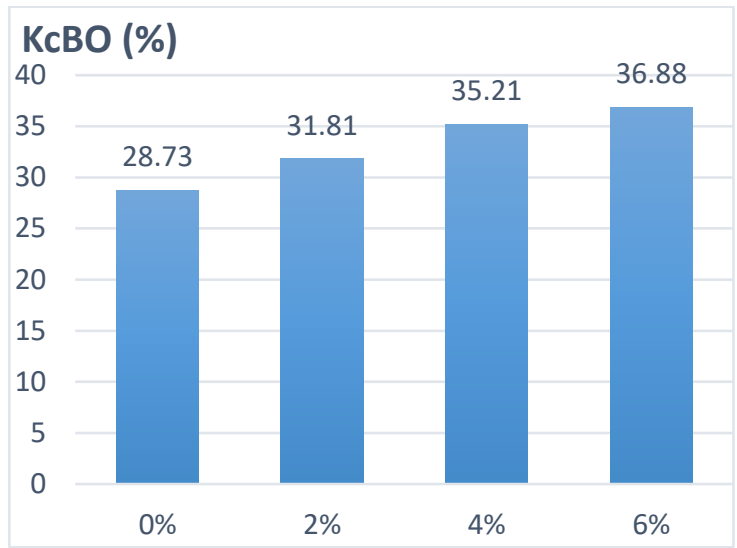

(b)

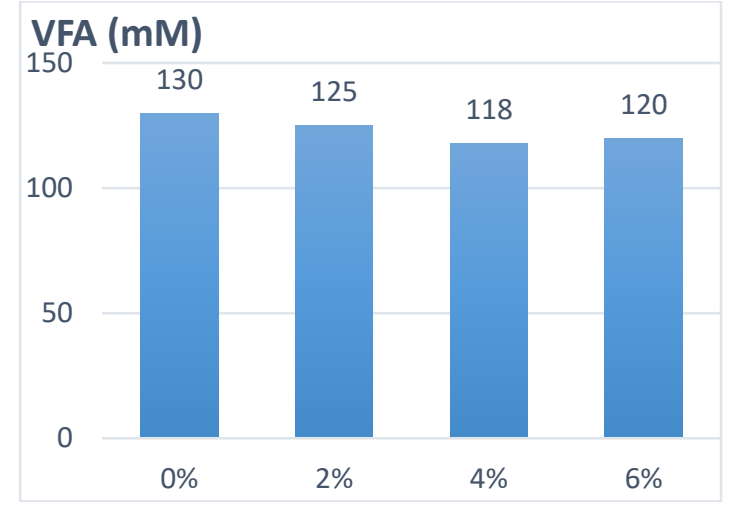

(c)

Gambar 1. Nilai rataan parameter penelitian (a) Kecernaan Bahan Kering (KcBK), (b) Kecernaan Bahan Organik (KcBO), (c) Volatile fatty acid (VFA) (Average value of research parameters (a) Dry Matter Digestibility, (b) Organic Matter Digestibility, (c) Volatile fatty acid)

\section{Kecernaan Bahan Organik}

Berdasarkan analisis ragam pada perlakuan perbedaan aras starter berpengaruh nyata $(\mathrm{P}<0,05)$ meningkatkan Kecernaan Bahan Organik (KcBO) pada sabut kelapa difermentasi. Peningkatan KcBO dapat diakibatkan lignin yang membentuk senyawa kompleks pada bahan pakan merenggang dan menjadi senyawa yang lebih sederhana. Ikatan lignin yang merenggang karena aktivitas enzim selulase. Enzim selulase dihasilkan oleh bakteri selulolitik selama proses fermentasi bahan pakan. Enzim selulase akan memecah selulosa menjadi gula sederhana. Nurhajati dan Suprapto (2013) menyatakan bahwa bakteri selulolitik menghasilkan enzim selulase dan merupakan enzim kompleks yang terdiri dari beberapa tahapan dalam menguraikan selulosa menjadi glukosa. Ikatan senyawa kompleks yang telah merenggang menjadi lebih sederhana membuat $\mathrm{KcBO}$ meningkat. Dewi et al., (2012) menyatakan peningkatan aktivitas mikrobia rumen dalam menghasilkan enzim selulase dapat meningkatkan metabolisme mikrobia, sehingga kecernaan bahan organik meningkat.

Kecernaan bahan organik pada sabut kelapa difermentasi pada perlakuan $\mathrm{T}_{0}, \mathrm{~T}_{1}, \mathrm{~T}_{2}, \mathrm{~T}_{3}$ berturut-turut yaitu, 28,73\%, 31,81\%, 35,21\% dan $36,88 \%$ (Tabel 1 dan Gambar 2). Perlakuan pada aras starter $6 \%\left(\mathrm{~T}_{3}: 36,88 \%\right)$ memiliki nilai rataan $\mathrm{KcBO}$ tertinggi dan berbeda tidak nyata dengan aras $4 \%\left(\mathrm{~T}_{2}: 35,21 \%\right)$ tetapi berpengaruh nyata lebih tinggi dari aras $2 \%\left(\mathrm{~T}_{1}: 31,81 \%\right)$ dan $0 \%$ $\left(\mathrm{T}_{0}: 28,73 \%\right)$. Nilai rataan $\mathrm{KcBO}$ relatif rendah tetapi mengalami peningkatan. Fathul dan Wajizah (2010) menyatakan nilai kecernaan pakan yang baik yaitu, lebih dari $60 \%$. Nilai $\mathrm{KcBO}$ meningkat (Gambar 2) sejalan dengan KcBK tetapi relatif lebih tinggi dibandingkan KcBK dapat diakibatkan dalam fermentasi mikrobia mendegradasi bahan organik dan tidak mendegradasi bahan anorganik. Pujowati et al., (2012) menyatakan KcBO memiliki kecernaan yang sejalan dengan KcBK karena komponen 
bahan organik sama dengan bahan kering kecuali pada kandungan abu. Peningkatan KcBO diduga kandungan tanin yang terkandung dalam sabut kelapa difermentasi mengalami penurunan selama proses fermentasi. Kandungan tanin yang tinggi akan mengakibatkan mikrobia sulit mendegradasi pakan karena memproteksi nutrien pakan, sehingga KcBO menurun. Lisan (2015) menyatakan bahwa tanin yang terkandung dalam sabut kelapa tua sekitar 4,28\% dan sabut kelapa muda sekitar 5,68\%. Faktor lain yang dapat mempengaruhi KcBO yaitu komposisi bahan pakan, perlakuan bahan pakan, perbandingan komposisi bahan pakan satu dengan lainnya, suplementasi enzim dalam bahan pakan, jenis ternak dan taraf pemberian pakan (McDonald et al., 2002).

\section{Produksi Volatile Fatty Acids}

Berdasarkan hasil perhitungan rataan produksi Volatile Fatty Acids (VFA) sabut kelapa yang difermentasi diperoleh data $\mathrm{T}_{0}, \mathrm{~T}_{1}, \mathrm{~T}_{2}, \mathrm{~T}_{3}$ berturut-turut yaitu, $130 \mathrm{mM}, 125 \mathrm{mM}, 118 \mathrm{mM}$ dan $120 \mathrm{mM}$ (Tabel 1). Nilai rataan produksi VFA sesuai standar dan baik untuk perkembangan mikrobia rumen. Badarina et al., (2014) menyatakan produksi VFA yang optimal bagi perkembangan mikrobia rumen berkisar 80-160 $\mathrm{mM}$. Hasil analisis ragam pada sabut kelapa yang difermentasi dengan aras starter yang berbeda berpengaruh tidak nyata terhadap produksi VFA. Produksi VFA sabut kelapa difermentasi memiliki kecenderungan menurun (Gambar 3). Produksi VFA berpengaruh tidak nyata dapat diakibatkan dalam proses fermentasi awal mikrobia memanfaatkan karbohidrat mudah dicerna, hal ini didukung hasil penelitian Ramadhani (2019) bahwa BETN pada sabut kelapa fermentasi, yaitu $16,15 \%\left(\mathrm{~T}_{0}\right), 17,26 \%\left(\mathrm{~T}_{1}\right), 15,21 \%\left(\mathrm{~T}_{2}\right) 13,93 \%$ $\left(\mathrm{T}_{3}\right)$. Kandungan BETN yang menurun mengakibatkan proporsi serat kasar meningkat, sehingga aktivitas mikrobia rumen menurun. Anindita (2010) menyatakan bahwa kandungan karbohidrat struktural yang tinggi mengakibatkan kandungan karbohirat non struktural (pati, glukosa dan fruktosa) pada bahan pakan lebih cepat difermentasi menjadi VFA oleh mikrobia rumen dan karbohidrat struktural lebih lambat didegradasi menjadi VFA. Produksi VFA sangat dipengaruhi oleh karbohidrat karena sebagian besar VFA hasil dari fermentasi karbohidrat dan sebagian berasal dari protein pakan. Tillman et al., (1998) menyatakan bahwa VFA merupakan produk hasil degradasi karbohidrat dan sebagian dari degradasi lemak dan protein dalam cairan rumen.
Faktor lain yang dapat mempengaruhi produksi VFA yaitu diduga VFA segera dimanfaatkan untuk biosintesis protein mikrobia, sehingga produksi VFA memiliki kecenderungan menurun, hal ini didukung hasil penelitian Pratama (2019) bahwa kandungan $\mathrm{NH}_{3}$ dan protein total pada sabut kelapa difermentasi pada tiap perlakuan secara berturut-turut, yaitu $\mathrm{NH}_{3}$ : 4,05 mM ( $\left.\mathrm{T}_{0}\right), 3,89 \mathrm{mM}\left(\mathrm{T}_{1}\right), 3,71 \mathrm{mM}\left(\mathrm{T}_{2}\right), 3,56$ $\mathrm{mM}\left(\mathrm{T}_{3}\right)$ dan protein total : 10,14 mg/g $\left(\mathrm{T}_{0}\right), 10,26$ $\mathrm{mg} / \mathrm{g}\left(\mathrm{T}_{1}\right), 11,50 \mathrm{mg} / \mathrm{g}\left(\mathrm{T}_{2}\right), 11,00 \mathrm{mg} / \mathrm{g}\left(\mathrm{T}_{3}\right)$. Prekusor biosintesis protein mikrobia yaitu VFA, $\mathrm{NH}_{3}$ dan rantai karbon yang berguna untuk menunjang biosintesis protein mikrobia. Volatile fatty acids berguna sebagai sumber energi dalam biosintesis protein mikrobia. Biosintesis protein mikrobia akan meningkat bila ketersediaan energi, $\mathrm{NH}_{3}$ dan kerangka karbon sebagai prekusor biosintesis terpenuhi. Kerangka karbon yang diperlukan untuk biosintesis protein mikrobia utamanya berasal dari senyawa intermedia dalam jalur katabolisme karbohidrat menjadi VFA (Irvani, 2011).

\section{SIMPULAN}

Pemberian aras starter mampu meningkatkan $\mathrm{KcBK}$ dan $\mathrm{KcBO}$ dan produksi VFA memiliki kecenderungan menurun serta pemberian aras starter optimal pada level $4 \%$.

\section{DAFTAR PUSTAKA}

Anindita, H. A. 2010. Pengaruh Level Isolate Mikrobia dan Lama Fermentasi Pelepah Sawit terhadap Produksi Amonia dan Protein Ruminal secara In vitro. Skripsi. Fakultas Peternakan dan Pertanian. Universitas Diponegoro. Semarang.

Anindyawati, T. 2009. Prospek enzim dan limbah lignoselulosa untuk produksi bioetanol. $J$. Bio. Sci. 44(1): 49-56.

Badarina, I., D. Evvyernie, T. Taharmat, dan E. N. Herliyana. 2014. Fermentabilitas rumen dan kecernaan in-vitro ransum yang disuplementasi kulit buah kopi produk fermentasi jamur Pleurotus ostreatus. J. Sains Pet. Indo. 9(2): 102-109.

Bondra, M., A. P. Setiawan, dan P. F. Nilasari. 2018. Penelitian serabut kelapa sebagai material lantai ecofriendly dan biodegradable. J. Intra. 6 (2): 431-436.

Departement of Dairy Science. 1966. General Laboratory Procedures. University of Winconsin. Madinson.

Dewi, N. K., S. Mukodiningsih, dan C. I. Sutrisno. 2012. Pengaruh fermentasi kombinasi 
jerami padi dan jerami jagung dengan aras isi rumen kerbau terhadap kecernaan bahan kering dan bahan organik secara in-vitro. J. Anim. Agr. 1(2): 134-140.

Direktorat Jendral Perkebunan (Ditjenbun). 2016. Stastistik Perkebunan Indonesia 20152017. Direktorat Jendral Perkebunan. Jakarta.

Fathul, F. dan S. Wajizah. 2010. Penambahan mikromineral $\mathrm{Mn}$ dan $\mathrm{Cu}$ dalam ransum terhadap aktivitas biofermentasi rumen domba secara in vitro. JITV. 15(1): 9-15.

Fariani, A. dan S. Akhadiarto. 2009. Pengaruh perlakuan alkali pada limbah kulit kopi dan peningkatan kecernaan dengan teknik in vitro. J. Rek. Ling. 5(2): 85-93.

Irvani, M. I. 2011. Pengaruh Proteksi Tanin Ampas Teh pada Aras yang berbeda terhadap Gamal (Gliricidia sepium) ditinjau dari Fermentabilitas dan Kecernaan secara In vitro. Skripsi. Fakultas Peternakan dan Pertanian. Universitas Diponegoro. Semarang.

Lisan, F. R. 2015. Penentuan jenis tanin secara kualitatif dan penetapan kadar tanin dari serabut kelapa (Cocos nucifera L.) secara permanganometri. J. Ilmiah Mahasiswa Universitas Surabaya. 4(1): 1-16.

McDonald, P., Edwards, R. A., Greehalgh, J. F. D. and Morgan, C. A. 2002. Animal Nutrition. $6^{\text {th }}$ Ed. Ashford Color Pr. Gosport.

Muchlas, M., Kusmartono, dan Marjuki. 2014. Pengaruh penambahan daun pohon terhadap kadar VFA dan kecernaan secara in-vitro ransum berbasis ketela pohon. $J$. Ilmu Pet. 24 (2): 8-19.

Nurhajati, T. dan T. Suprapto. 2013. Penurunan serat kasar dan peningkatan protein kasar sabut kelapa (Coco nucifera Linn) secara amofer dengan bakteri selulolitik (Actinobacillus ML-08) dalam pemanfaatan limbah pasar sebagai sumber bahan pakan. J. Agrovet. 2(1): 1-11.

Oladayo, A. 2010. Proximate composition of some agricultural wastes in Nigeria and their potential use in activated carbon production. J. Appl. Sci. Environ. Manag. 14(1): 55-58.

Pratama, G. P. 2019. Produksi Amonia $\left(\mathrm{NH}_{3}\right)$, Protein Mikroba dan protein Total pada Sabut Kelapa Fermentasi secara In vitro. Skripsi. Fakultas Peternakan dan Pertanian. Universitas Diponegoro. Semarang.

Pujowati, A., Sutrisno dan E. Pangestu. 2012. Kecernaan dan poduksi volatile fatty acids pakan komplit yang mengandung tepung kedelai dengan perlakuan pemanasan secara in vitro. J. Anim. Agr. 1(2): 151156.

Rahayu, R. I., A. Subrata, dan J. Achmadi. 2018. Fermentabilitas ruminal in vitro pada pakan berbasis jerami padi amoniasi dengan suplementasi tepung bonggol pisang dan molasses. J. Pet. Indo. 20(3): 166-174.

Ramadhani, M. 2019. Kadar Serat Kasar, Protein Kasar dan Total Digestible Nutrients pada Sabut Kelapa (Cocos Nucifera) yang Difermentasi dengan Level Starter yang Berbeda. Skripsi. Fakultas Peternakan dan Pertanian. Universitas Diponegoro. Semarang.

Riswandi, Muhakka, dan M. Lehan. 2015. Evaluasi nilai kecernaan secara in vitro ransum ternak sapi bali yang disuplementasi dengan probiotik bioplus. J. Pet. Sriwijaya. 4 (1): 35-46.

Simbolon, N., R. I. Pujaningsih, dan S. Mukodiningsih. 2016. Pengaruh berbagai pengolahan kulit singkong terhadap kecernaan bahan kering dan bahan organik secara in vitro, protein kasar dan asam sianida. J. Ilmu Pet. 26(1): 58-65.

Soares, D., I. H. Djunaidi, dan M. H. Natsir. 2018. Pengaruh jenis inoculum Aspergilus niger, Saccharomyces cereviseae dan lama fermentasi terhadap komposisi nutrien ampas putak (Chorypha gebanga). J. Ilmu Pet. 28(1): 90-95

Sukarti, E., B. Sulistiyanto, dan S. Mukodiningsih. 2012. Kualitas serat limbah pertanian dan hasil samping pertanian yang difermentasi dengan Aspergilus niger pada aras dan lama pemeraman yang berbeda. J. Anim. Agr. 1(2): 77-85.

Tillman, A. D., H. Hartadi, S. Reksohadiprodjo, S. Prawirokusumo dan S. Lebdosoekojo. 1998. Ilmu Makanan Ternak Dasar. Edisi ke 6. Universitas Gadjah Mada. Yogyakarta.

Widodo, F. Wahyono, dan Sutrisno. 2012. Kecernaan bahan kering, kecernaan bahan organik, produksi VFA dan $\mathrm{NH}_{3}$ pakan komplit dengan level jerami padi berbeda secara in vitro. J. Indo. Food Tech. 1(1): $1-15$. 